\title{
Environmental Comparison of Different Transport Modes
}

\author{
Tomáš Skrúcaný \\ University of Žilina \\ Faculty of Operation and Economics of \\ Transport and Communications \\ Department of Road and Urban Transport \\ Slovak Republic \\ e-mail: tomas.skrucany@fpedas.uniza.sk
}

\author{
Martin Jurkovič \\ University of Žilina \\ Faculty of Operation and Economics of \\ Transport and Communications \\ Department of Water Transport \\ Slovak Republic \\ e-mail: martin.jurkovic@fpedas.uniza.sk
}

\author{
Martin Kendra \\ University of Žilina \\ Faculty of Operation and Economics of \\ Transport and Communications \\ Department of Railway Transport \\ Slovak Republic \\ e-mail: martin.kendra@fpedas.uniza.sk
}

\author{
Tomáš Kalina \\ University of Žilina \\ Faculty of Operation and Economics of \\ Transport and Communications \\ Department of Water Transport \\ Slovak Republic \\ e-mail: tomas.kalina@fpedas.uniza.sk
}

\author{
Martin Vojtek \\ University of Žilina \\ Faculty of Operation and Economics of \\ Transport and Communications \\ Department of Railway Transport \\ Slovak Republic \\ e-mail: martin.vojtek@fpedas.uniza.sk \\ František Synák \\ University of Žilina \\ Faculty of Operation and Economics of \\ Transport and Communications \\ Department of Road and Urban Transport \\ Slovak Republic \\ e-mail: frantisek.synak@fpedas.uniza.sk
}

DOI 10.17818/NM/2018/4SI.5

UDK 620.9:656.1/.6

Original scientific paper

Paper accepted: 28. 8. 2018.

\section{Summary}

The paper describes the energy consumption and GHG production comparison of three transport modes - road, rail and waterborne. The calculations are done according to the legislation in force - standard EN 16 258:2012 Methodology for calculation and declaration of energy consumption and GHG emissions of transport services (freight and passengers). The results have high informative value because they take into account energy consumption and emissions from primary and secondary consideration. The calculation is done by real fuel consumption values (road and waterborne) and by simulation of energy consumption (railway). The energy and emission coefficients from the standard EN were used for estimating the results according to the well-to-wheels and tank-to-wheels principles.

\section{KEY WORDS}

energy consumption

GHG production

road transport

rail transport

water transport

\section{INTRODUCTION}

The current economic situation is directly dependent on transport. The follow-up activities leading to the creation of value products and services that meet the needs of the society and the individual could not be implemented without the transport of goods or services to the population [1-3].

During the transportation process the energy movesvehicles which provide the required transfer of goods and people in the area. Therefore, the transport depends on the supply of energy [4-7]. Today transportation is largely dependent on oil, as the vast majority ofvehicles are driven by engines which combust petroleum products - hydrocarbon fuels. This particularly refers to the road, air and water transport. Most rail vehicles are now powered by electric traction motors, so they do not depend on oil as much as the above-mentioned modes of transport [8-11]. But the fact is that in most countries the electricity is produced through petroleum products or coal. These are non-renewable natural resources and their stocks have steadily declined.

Given the above, it is an effort to streamline the transport of energy dependence, as suggested by the legislative measures such as the White Book at the EU level or different policies and programs at the national state level [12-15].

Vehicle energy consumption represents the highest energy intensity of each mode of transport.

\section{STANDARD EN 16258:2012 AND ITS USING IN CALCULATIONS}

This European Standard EN 16258:2012 Methodology for calculation and declaration of energy consumption and GHG emissions of transport services (freight and passengers) specifies general methodology for calculation and declaration of energy consumption and greenhouse gas emissions (GHG) in connection with the provided services (cargo, passengers or both). It specifies general principles, definitions, system boundaries, methods of calculation, allocation rules (allocation, assignment) and recommendations on information to support the standardized, accurate, reliable and verifiable declarations regarding energy consumption and greenhouse gas emissions associated with the freight service. It also contains examples of the use of these principles.

The calculation for one given transport service must be performed using the following three main steps:

- step 1: identification of the various sections of the service,

step 2: calculation of energy consumption and greenhouse gas emissions for each section,

- step 3: sum the results for each section [16].

The standard does not consider only the secondary emissions produced and energy consumed during the fuel combustion (energy conversion from fuel to mechanical energy), as well as 
primary, incurred in the extraction, production and distribution. - $\quad e_{w}$ - well-to-wheels energetic factor for the defined fuel, - $\quad g_{w}$ - well-to-wheels emissions factor for the defined fuel, - $e_{t}$ - tank-to-wheels energetic factor for the defined fuel, - $g_{t}$ - tank-to-wheels emissions factor for the defined fuel. Well-to-wheels is "well on wheels", that also covers primary and secondary emissions and consumption. Somewhere this factor is also called as LCA (life-cycle-analysis).

Tank-to-Wheels factor is thinking only of secondary emission and consumption.

This Standard specifies the general methodology for calculation and the declared value for the energetic factor. The factor in greenhouse gas emissions must be selected in accordance with Annex A [16].

Emission gases are composed of several individual components (gas). Each one has different chemical and physical properties and participates in environmental degradation. In order to compare emissions from different activities, fuels, vehicles, where emissions have different track, and one representative unit must be designed for the purpose of comparison. This is the $\mathrm{CO}_{2}$ equivalent, which is a measure of the specific emissions impact similar to the impact of $\mathrm{CO}_{2}$. The label is $\mathrm{CO}_{2 \mathrm{e}}$ (equivalent).

\section{ENERGY CONSUMPTION}

Energy and emission factor $\left(e_{w^{\prime}} g_{w}\right)$ reflects a partial loss of production and distribution of power energy in the chain:

- energy mixture used in the manufacture of electric energy,

efficiency of various energy sources,

- transfer efficiency (distribution) el. supply to the final consumer.

Due to these facts the effectiveness (efficacy) of the el. energy is directly related to power production technology.

Energy efficiency in electricity production can be calculated as a weighted arithmetic mean of primary resources and efficiency from various energy sources. Weight values represent the proportions of the various sources.

Produced energy gets to consumers through the transmission system. Recent losses in the transmission of produced energy power in locomotive wheels are custom transmission losses from conduction through the collector and control system of the locomotive. The efficiency of this process is approximately $90 \%$. So overall energy efficiency supplied power for the rail transport is:

$$
\eta_{T}=\eta_{P} \cdot \eta_{T L} \cdot \eta_{V S}=\left(\sum\left(\eta_{Z i} \cdot p_{Z i}\right) / p_{Z}\right) \cdot \eta_{T L} \cdot \eta_{V S}
$$

where:

- $\quad \eta_{T}$ - overall energy efficiency (-),

$\eta_{p}$ - efficiency of power. energy (-),

$\eta_{\mathrm{TL}}$ - power transfer efficiency $(-)$,

$\eta_{\mathrm{vs}}$ - efficiency of vehicle system (-),

$\eta_{\mathrm{Zi}}$ - effectiveness of a particular primary source $(-)$,

$\mathrm{p}_{\mathrm{Zi}}$ - share of a given resource in the production of electric power (-),

$\mathrm{p}_{\mathrm{z}}$ - sum of partial fractions of the individual sources (-).

\section{PRODUCTION OF EMISSIONS AND ELECTRIC ENERGY}

The same procedure can be used to calculatethe total energy efficiency for the emissions production. The procedure is the same, based on the share of individual sources and their emissions. Thearithmetic mean was used for the results. The socalled emission factor is the easier way. This value is calculated for each country and includes the overall efficiency of electricity in a particular country along with the vehicle efficiency. Therefore, this emission factor should be used to compare the country without a lengthy search of sub efficiency and emissions.

\section{CALCULATION OF ENERGY CONSUMPTION AND EMISSION PRODUCTION}

\subsection{Railway transport}

Software Railway dynamics has been used to calculate the energy consumption of the train. This software calculates the power consumption of the train based on the predefined and selected values for the defined route. The software works with maps and elevation profile rail routes. Based on these defaults and selected characteristics (type of locomotive, train weight, train length, axle load, number and location of stops) the power consumption in kWh is calculated [6], [18].

The output consumption data were defined for further calculations and comparisons.

Calculated energy is the mechanical work needed to move the train. After transforming it into units of $\mathrm{MJ}$, it is subsequently converted to the total consumed energy by an overall energy

Table 1 LCA emission factors of EU-27 countries

\begin{tabular}{|l|c|c|c|}
\hline \multicolumn{1}{|c|}{ Country } & $\begin{array}{c}\text { LCA emission factor } \\
\text { (tCO } \mathrm{e} / \mathrm{MWh})\end{array}$ & \multicolumn{1}{c|}{ Country } & $\begin{array}{c}\text { LCA emission factor } \\
\text { (tCO } \mathrm{e} / \mathrm{MWh})\end{array}$ \\
\hline Austria & 0.310 & Sweden & 0.079 \\
\hline Belgium & 0.402 & Bulgaria & 0.906 \\
\hline Germany & 0.706 & Cyprus & 1.019 \\
\hline Denmark & 0.760 & Czech Republic & 0.802 \\
\hline Spain & 0.639 & Estonia & 1.593 \\
\hline Finland & 0.418 & Hungary & 0.678 \\
\hline France & 0.146 & Lithuania & 0.174 \\
\hline UK & 0.658 & Latvia & 0.563 \\
\hline Greece & 1.167 & Poland & 1.185 \\
\hline Ireland & 0.870 & Romania & 1.084 \\
\hline Italy & 0.708 & Slovenia & 0.602 \\
\hline Netherlands & 0.716 & Slovakia & 0.353 \\
\hline Portugal & 0.750 & EU-27 average value & 0.578 \\
\hline
\end{tabular}


efficiency of equation (1) [18].

where:

$$
E_{T}=\left(E_{M E} \cdot 3.6\right) \cdot \eta_{C E}
$$

- $\mathrm{E}_{\mathrm{T}}$ - total energy consumed electric traction (MJ),

- $\quad E_{M E}$ - mechanical energy consumed by the movement of the train (train dynamics software result) ( $\mathrm{kWh}$ ).

The LCA emission factor (EU-27 average value) was used to calculate the amount of produced emissions (table 1). The train consumed energy (MJ) is computed by dividing the mechanical work and the efficiency of the vehicle [18].

$$
\begin{array}{cc}
G_{T}=\left[\left(E_{M E} / \eta_{V S}\right) \cdot 1000\right] \cdot f_{L C A} & \left(\mathrm{tCO}_{2 \mathrm{e}}\right) \\
G_{T}=\left[\left(E_{M E} / \eta_{V S}\right) \cdot 3.6\right] \cdot f_{L C A}^{g} & \left(\mathrm{gCO}_{2 \mathrm{e}}\right)
\end{array}
$$

where:

- $\mathrm{G}_{\mathrm{T}}$ - total amount of emissions produced by electric traction,

- $f_{L C A}$ - emission factor for electric energy ( $\left(\mathrm{CO}_{2 \mathrm{e}} / \mathrm{MWh}\right)$,

- $f_{\mathrm{LCA}}^{\mathrm{L}}$ - emission factor for electric energy $\left(\mathrm{gCO}_{2 \mathrm{e}} / \mathrm{MJ}\right)$.

\subsection{Road transport}

To calculate the total energy consumption of road transport, the amount of consumed fuel by road vehicle should be multiplied by energy factor for that fuel from Appendix A of the standard.

$$
E_{T V}=\left[\left(F C_{k m} \cdot L\right) / 100\right] \cdot e_{W}
$$

where:

- $\mathrm{E}_{\mathrm{TV}}$ - total energy consumed by vehicles (MJ),

- $\quad \mathrm{FC}_{\mathrm{km}}$ - vehicle fuel consumption (l/100km),

$\mathrm{L}$ - driven distance $(\mathrm{km})$,

- $e_{\mathrm{w}}$ - energetic factor "wtw" for defined fuel (MJ/I).

To calculate the total GHG production, the consumed amount of fuel should be multiplied by an emission factor for that fuel from Appendix A of the standard.

$$
G_{T V}=\left[\left(F C_{k m} \cdot L\right) / 100\right] \cdot g_{W} \quad\left(\mathrm{gCO}_{2 \mathrm{e}}\right)
$$

where:

- $\mathrm{G}_{\mathrm{TV}}$ - total amount of emissions produced by vehicles $\left(\mathrm{gCO}_{2 \mathrm{e}}\right)$, - $g_{w}$ - emission factor for defined fuel $\left(\mathrm{tCO}_{2 \mathrm{e}} / \mathrm{MJ}\right)$.

\subsection{Water transport}

Consumed fuel by water transport was finding by the real measurement on vessel in real operation on river. To calculate the total energy consumption and GHG production of water transport, the amount of consumed fuel by vessel should be multiplied by energy factor and emission factor for that fuel from Appendix A of the standard. These are similar process of calculation to the road transport operation with small diversions - values from water transport operator are in the absolute amount of fuel (total volume of consumed fuel per shipping) and it is not necessary to multiple the $\mathrm{FC}_{\mathrm{km}}$ and L [19-22].

\section{MODEL STUDY}

In this case study here is model transportation of $2100 \mathrm{t}$ bulk cargo (compost plant) by freight trains, road vehicles and vessels as a direct transportation between two places with the distance of $260 \mathrm{~km}$.

Compost plant can be stored and transported in open air. Bulk density of compost is $1200-1400 \mathrm{~kg} / \mathrm{m}^{3}$. It also depends on the humidity of the substrate. The mean value was 1300 $\mathrm{kg} / \mathrm{m}^{3}$.

Calculation of the energy consumption of road transport was considered with consumption of $28 \mathrm{I} / 100 \mathrm{~km}$ fuel at long distances. This value rises on shorter distance because the vehicle consumes more energy to start-up and for the standby operating mode [23-27].

Road vehicles are articulated semitrailer sets with dump body made of aluminium. Their less weight is $13 \mathrm{t}$, the payload $27 \mathrm{t}$ and the body capacity $24 \mathrm{~m}^{3}$. Considering the maximal weight limit ( $40 \mathrm{t}$ ) it is possible to load only $20.8 \mathrm{~m}^{3}$ of cargo (87 $\%$ of capacity). Road vehicles have priority to use highways and expressways [28-31].

The train is composed of 43 Faccs wagons and locomotives Skoda E69 and E 479. The locomotives are used according to the track elevation (needed higher pulling power). This train is 620 $\mathrm{m}$ long and its gross weight is $3198 \mathrm{t}$. The payload represents $2100 \mathrm{t}$ [3], [6], [31].

The 3 train stops during transporting. That is the presumed value of operating on the defined route and the distance.

Vessel set consist of TR MOUFLON and two boats DE II.b. Vessel TR MUFLON was built in shipyard Wroclaw under supervision of Polish estate register. The vessel is equipped with two 5 -sheet propellers $\theta 1300 \mathrm{~mm}$ set in fixed nozzle. Steering device consists of $2 \times 2$ pieces of fins with proportional turning for moving forward [20], [21].

Here are the other power characteristics:

- main motors: 2 x MAN D2842 LE 4122 x 588 kW at $1800 \mathrm{rev} /$ $\min$,

- mensural diesel consumption at $100 \%$ load: $205 \mathrm{~g} / \mathrm{kWh}$,

subsidiary motors: 2 x Deutz BF4M 2012C,

mensural diesel consumption at $100 \%$ load: $243 \mathrm{~g} / \mathrm{kWh}$,

real average diesel consumption: 90 - $140 \mathrm{l} / \mathrm{h}$,

diesel reserve: $16.8 \mathrm{t}(20000 \mathrm{I})$,

max. shipping independence: $140 \mathrm{~h}$ with netto mass $158 \mathrm{t}$.

An approximate duration of the navigation is 26 hour downstream of the river and 47 hours upstream based on the standard nautical terms, i.e. on the water and weather conditions permitting safe shipping.

Diesel consumption and shipping time data are related to the load of $190-200 \mathrm{~cm}$, which represents $1.000-1.100 \mathrm{t}$ for one boat. This means that the set capacity is $2.000-2.200 \mathrm{t}$ [20], [21].

Table 2 Vessel set technical parameters

\begin{tabular}{|c|c|c|c|c|c|c|}
\hline Vessel & $\begin{array}{c}\text { Length } \\
(\mathrm{m})\end{array}$ & $\begin{array}{c}\text { Width } \\
(\mathrm{m})\end{array}$ & Side height $(\mathrm{m})$ & $\begin{array}{c}\text { Dive } \\
(\mathrm{m})\end{array}$ & Power $(\mathrm{kW})$ & Capacity $(\mathrm{t})$ \\
\hline TR Mouflon & 23.1 & 8.9 & 2.0 & 1.2 & $566 / 840$ & - \\
\hline Boat DE II.b & 76.5 & 11 & 3.2 & 2.7 & - & 1600 \\
\hline
\end{tabular}

Source: authors 
Table 3 Vessel diesel consumption

\begin{tabular}{|l|c|}
\hline \multicolumn{1}{|c|}{ Route } & Diesel consumption (I) \\
\hline Upstream shipping & 7618 \\
\hline Downstream shipping & 2188 \\
\hline Source: authors & \\
\hline
\end{tabular}

Table 4 Entry parameters values for calculation of mensural emissions

\begin{tabular}{|c|c|c|}
\hline Motor & Unit & Consumption* \\
\hline 2 x MAN D2842 LE 412 & $\mathrm{kg} / \mathrm{h}$ & 130.54 \\
\hline 2 x Deutz BF4M 2012C & $\mathrm{kg} / \mathrm{h}$ & 25.2 \\
\hline
\end{tabular}

* Precondition of $100 \%$ load during the whole time of operation Source: authors

\section{EVALUATION}

This part shows a graphical evaluation of the above mentioned case study. All calculations were done according to the legal standard EN 16258 on the basis of real measured values or simulated values of fuel and energy consumption.

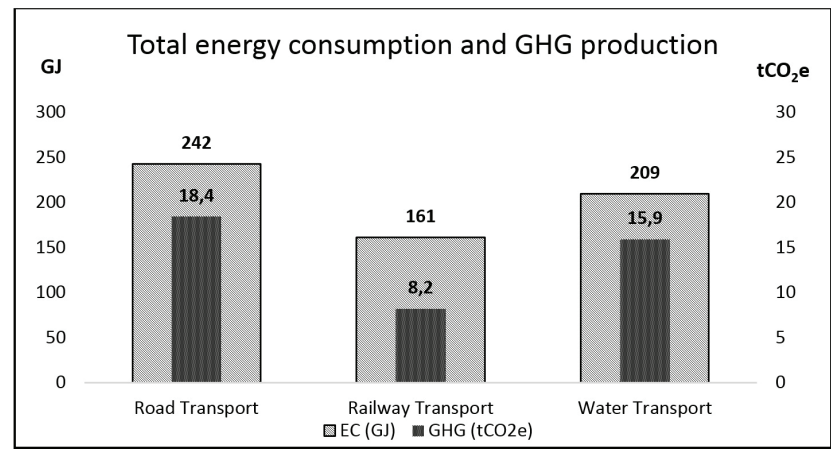

Figure 1 Total energy consumption and GHG production Source: authors

Fig. 1 represents the absolute values of consumed energy and produced GHG for the solved freight case. The most effective is railway transport. This fact can be proven by lower driving resistances than in road and water transport and also by higher efficiency of the locomotive electric engine. Engines for electric traction reach the efficiency value at about $90 \%$ but the diesel engines (used in road and water transport) only $40 \%$. This fact affects also the level of GHG production but not proportionally.

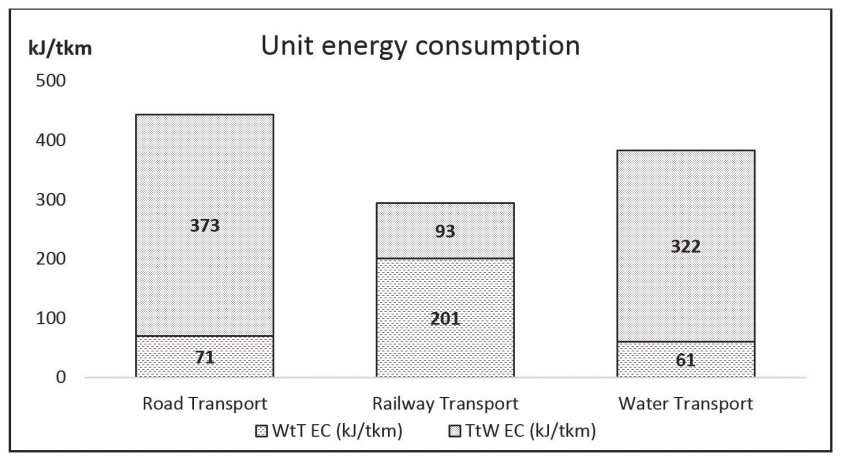

Figure 2 Unit energy consumption
T principle Well-to-Wheels (WtW) was used to estimate the results. This principle considers primary and secondary energy consumption and GHG production together. For higher representative value it is useful to share this principle on two parts - Well-to-Tank (WtT) which represents only secondary effects (production and distribution of the fuel or energy) and Tank-to-Wheels (TtW) which means the final consumption of fuel or energy directly by transport vehicle (f.e. automobile fuel consumption). These two parts represent the global environmental impact WtW.

Fig. 2 describes the diversion in primary and secondary energy consumption of fossil fuels (diesel) and electric power. Vehicle with diesel traction reaches higher values of energy consumption in TtW principle because of lower engines efficiency and high calorific value of diesel. This vehicle reaches lower values of secondary energy consumption (WtT). Production and distribution of diesel is not as intense as the electric power production. Efficiency of electric power production and distribution depends on primary sources but mostlyreaches the value of around $35 \%$.

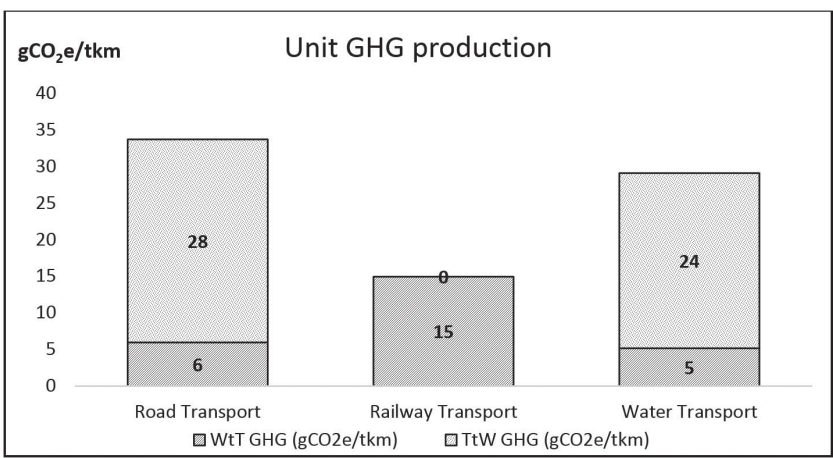

Figure 3 Unit GHG production

Source: authors

Graphical evaluation of unit GHG production describes the effect of "zero emission" electric traction. This fact is not completely true. Zero emission level reaches this traction only by taking into consideration the TtW principle, so the electric powered vehicle produces no emission in its actual location. But globally, the electric traction produces GHG during its production - changing primary sources into electric power. The mixture of these sources affects also the emission level (GHG production intensity). Vehicle which used electric power produced in countries where primary source for production of electricity is mainly coal, it will be never less GHG intense than other diesel powered vehicle. It was calculated with EU average level of electric emission factor (table 1) in this model study. The electric powered railway transport produces less GHG than diesel powered road or water transport vehicles.

\section{CONCLUSION}

In order to make the transport of goods sustainable, it is important to use the most of the transport modes which in terms of the energy consumption and GHG production are the most environmental friendly. The energy intensity and GHG emissions in transport depend on the available transport infrastructure, the choice of the suitable vehicles, the quantity 
and nature of the transported goods and the traction or fuel used. Primary as well as secondary energy consumption must be taken into account in assessing the energy intensity and GHG production. An important factor that is often forgotten is that even electric traction can have a very significant negative impact on the environment if the primary sources for its production are the fossil fuels.

\section{Acknowledgement}

This contribution/publication is the result of the projects implementation:

Centre of excellence for systems and services of intelligent transport II., ITMS 26220120050 supported by the Research \& Development Operational Programme funded by the ERDF.

Grant No. 1/0019/17 by the VEGA Agency "Evaluation of regional rail transport in the context of regional economic potential with a view to effective use of public resources and social costs of transport", at Faculty of Operations and Economics of Transport and Communication, University of Žilina, Slovakia.

\section{REFERENCES}

[1] Lizbetin, J., Stopka, O., Nemec, F. Methodological Assessment of Environmental Indicators in Combined Transport in Comparison with Direct Road Freight Transport. In: Proceedings of the 20th international scientific conference Transport means 2016, Kaunas, Lithuania, 2016, pp. 151-155.

[2] Bartuska, L., Biba, V., Kampf, R. Modeling of daily traffic volumes on urban roads. In: Proceedings of the third international conference on traffic and transport engineering (ICTTE), Belgrade, Serbia, 2016, pp. 900-904.

[3] Gasparik, J., Abramovic, B., Halas, M. New graphical approach to railway infrastructure capacity analysis. Promet-traffic \& transportation, 2015, Vol. 27, Issue 4, pp. 283-290. https://doi.org/10.7307/ptt.v27i4.1701

[4] Abramovic, B. Horizons of railway transport 2012 Globalization trends and their impact on the transport system in terms of the EU common market. Promet-traffic \& transportation, 2013, Vol. 25, Issue 2, pp. 191-192.

[5] Stoilova, S., Kunchev, L. Method for optimal transportation using a threephase model. Comptes rendus de L Academie Bulgare des sciences, 2016, Vol. 69, Issue 7, pp. 905-910.

[6] Masek, J., Camaj, J., Belosevic, I. Improving the transport capacity of the intermodal train and track based on different types of wagons. In: Proceedings of the third International Conference on Traffic and Transport Engineering (ICTTE), Belgrade, Serbia, 2016, pp. 409-416.

[7] Kubasakova, I., Jagelcak, J. Logistics system just-in-time and its implementation within the company. Communications: scientific letters of the University of Žilina, 2016, Vol. 18, No. 2 pp. 109-112. ISSN 1335-4205.

[8] Figlus, T. Diagnosing of valve clearance of the diesel engine. Scientific journal of Silesian university of technology-series transport, Gliwice, Poland, 2008 Vol. 64, pp. 113-122

[9] Kalincak, D., Bartik, L., Grencik, J. The hybrid traction - the way of fuel utilization improvement. Facta universitatis-series mechanical engineering, Nis, Serbia, 2012, Vol. 10, Issue 2, pp. 163-170.

[10] Kobryn, J., Figlus, T. Similarity numbers in the-zone combustion model. In: Scientific journal of Silesian university of technology-series transport, Gliwice, Poland, 2010, Vol. 67, pp. 75-82.

[11] Matuszak, Z. Components validity evaluation in a complex technical structure. Scientific journals of the Maritine university of Szczecin-zeszyty naukowe Akademii morskej w Szczecinie, 2012, Vol. 32, Issue 104, pp. 115-122.

[12] Knez, M., Jereb, B., Obrecht, M. Factors influencing the purchasing decisions of low emission cars: A study of Slovenia. Transportation research part D -
Transport and environment, 2014, Vol. 30, pp. 53-61. https://doi.org/10.1016/j. $\operatorname{trd} .2014 .05 .007$

[13] Knez, M., Muneer, T., Jereb, B. et al. The estimation of a driving cycle for Celje and a comparison to other European cities. Sustainable cities and society, 2014, Vol. 11, pp. 56-60. https://doi.org/10.1016/j.scs.2013.11.010

[14] Matuszak, Z. Estimation of the availability of the power-propulsion and technological system of a fishing vessel at selected operational model. Eksploatacja i niezawodnosc-maintence and reliability, 2010, Issue 1, pp. 49-58.

[15] Petro, F., Konecny, V. Calculation of emissions from transport services and their use for the internalisation of external costs in road transport. In: 12th International scientific conference of young scientists on sustainable, modern and safe transport, High Tatras, Slovakia, Procedia Engineering, 2017, Vol. 192, pp. 677-682. https://doi.org/10.1016/j.proeng.2017.06.117

[16] European standard EN 16 258:2012. Methodology for calculation and declaration of energy consumption and GHG emissions of transport services (freight and passengers).

[17] Technical annex to the SEAP template instructions document: The emission factors. Document of The European Commission.

[18] Skrucany, T., Gnap, J. Energy intensity and greenhouse gases production of the road and rail Cargo transport using a software in simulate the energy consumption of a train. In: Telematics - support of transport: 14th international conference on Transport systems telematics, TST 2014, Berlin: SPRINGER-VERLAG, 2014, pp. 263-272.

[19] Galierikova, A., Sosedova, J. Environmental aspects of transport in the context of development of inland navigation. Ekológia, 2016, Vol. 35, Issue 3, pp. 279288. https://doi.org/10.1515/eko-2016-0022

[20] Kalina, T., Jurkovic, M., Vyzinkar, P., Vaclavinek, P. Comparison of economic efficiency of LNG with traditional fuels in freight transport. In: Proceedings of the 21tst international scientific conference Transport means 2017, Kaunas, Lithuania, 2017, pp. 213-219.

[21] Jurkovic, M., Kalina, T., Teixeira, A. F. Possibilities of using alternative fuels for transport solution in Brazil. In: Proceedings of the 21st international scientific conference Transport means 2017, Kaunas, Lithuania, 2017, pp. 724-728.

[22] Jurkovic, M., Kalina, T., Turcan, R., Gardlo, B. Proposal of an enhanced safety system on board of the inland vessel. In: MATEC web of conferences. LOGI 2017 - 18th international scientific conference, Ceske Budejovice, Czech Republic, 2017, Vol. 134, art. No. 22.

[23] Liscak, S., Rievaj, V., Sulgan, M. Vehicle's technical condition and emission. Eksploatacja i niezawodnosc-maintence and reliability, 2008, Issue 1, pp. 61-63.

[24] Liu Jiangwei. Calculation and analysis of energy consumption of Chinese national rail transport. International Journal of Energy Sector Management, Emerald Publishing Limited, 2018. https://doi.org/10.1108/ IJESM-05-2016-0006

[25] Rievaj, V., Mokrickova, L., Rievaj, J. Impact of driving techniques on fuel consumption. Communications - Scientific Letters of the University of Zilina, 2016, Vol. 18, Issue 2, pp. 72-75.

[26] Polcar, A., Cupera, J., Kumbar, V. Calibration and its use in measuring fuel consumption with the can-bus network. Acta Universitatis Agriculturae et Silviculturae Mendelianae Brunensis, 2016, Vol. 64, Issue 2, pp. 503-507. https://doi.org/10.11118/actaun201664020503

[27] Šimková, I., Konečný, V., Kapusta, J. The definition of the freight road transport criteria. Logi - Scientific Journal on Transport and Logistics, 2015, Vol. 6, No. 1, pp. 120-129. ISSN 1804-3216.

[28] Sarkan, B., Holesa, L., Caban, J. Measurement of fuel consumption of road motor vehicle by outdoor driving testing. Advances in science and technology-research journal, 2013, Vol. 7, Issue 19, pp. 70-74. https://doi. org/10.5604/20804075.1062374

[29] Vrabel J., Jagelcak, J., Zamecnik, J., Caban J. Influence of Emergency Braking on Changes of the Axle Load of Vehicles Transporting Solid Bulk Substrates. In: Procedia Engineering, Transportation Science and Technology: Proceedings of the 10th International Scientific Conference, TRANSBALTICA 2017, Vol. 187, 2017, pp. 89-99.

[30] Jagelčák, J., Kubasáková, I. Load distribution in general purpose maritime container and the analysis of load distribution on extendable semitraile container chassis carrying different types of containers. Naše more, 2014, Vol. 61, Issue 5-6, pp. 106-116. ISSN 0469-6255.

[31] Bistak, M., Brumercik, F., Lukac, M. Weighing systems in traffic. Scientific journal of Silesian University of technology-series transport, Gliwice, Poland 2017, Vol. 97, pp. 5-15. https://doi.org/10.20858/sjsutst.2017.97.1 